\title{
Shear Bond Strength of Different Adhesive Systems on Enamel Prepared by Er: YAG LASER
}

\author{
Patrícia T. Pires ${ }^{1}$, João C. Ferreira², Álvaro F. Azevedo ${ }^{3}$, Sofia Arantes-Oliveira4, Walter R. Dias ${ }^{5}$, Paulo R. \\ Melo $^{6}$ \\ 1,23,6Department of Operative Dentistry, University of Porto, Rua Dr. Manuel Pereira da Silva S/N, 4200-393 Porto, \\ Portugal \\ 4Department of Operative Dentistry, University of Lisboa, Cidade Universitária, 1649-003 Lisboa, Portugal \\ 5Department of Dentistry, Charité University, De-Trey-Straße 1, 78467 Konstanz, Germany \\ ${ }^{1}$ ppires@fmd.up.pt; ${ }^{2}$ rcferreira@gmail.com; ${ }^{3}$ aazevedo@fmd.up.pt; ${ }^{4}$ sofiaaol@fmd.ul.pt; ${ }^{5}$ walterrldias@hotmail.com; \\ ${ }^{6}$ pmelo@fmd.up.pt
}

Received 16 October 2012; Accepted 18 May 2013; Published January 2014

(C) 2014 Science and Engineering Publishing Company

\begin{abstract}
To evaluate Shear Bond Strength (SBS) values of different dental adhesives on Er:YAG laser prepared enamel and bur prepared enamel, one hundred and fifty bovine incisors were randomly assigned to SBS tests on enamel $(n=15)$ in ten different groups. Groups 1 to 5 were prepared with Er:YAG laser. Groups 6 to 10 were mechanical prepared. Followed by: Group 1 and $6-37 \%$ phosphoric acid (PA) + ExciTE®; Group 2 and 7 - AdheSE®; Group 3 and 8 - FuturaBond $\AA$ NR; Group 4 and 9 - ExciTE®; Group 5 and $10-$ Xeno® V. After the adhesive systems samples were subjected to thermal cycling, SBS were performed in an universal testing machine at $5 \mathrm{~mm} / \mathrm{min}$. Data were treated with two-way ANOVA, and post-hoc test (Student knewman keuls) $(p<0,05)$. Chi-squared statistical tests were used to evaluate the type of fractures. Mean SBS values were Group 147,17+/-6,25MPa; Group 2-29,10+/-5,21MPa; Group 3-23,32+/ -5,93MPa; Group 4 - 32,56+/-6,36MPa; Group 5- 24,43+/-6,76 MPa; Group 6- 26,12+/-6,32 MPa; Group 7- 14,77+/-3,47MPa, Group 8- 21,03+/-7,44MPa, Group 9-3,25+/-2,91MPa; Group $10-16,38+/-7,64 \mathrm{MPa}$. Statistical analysis of the data revealed that different preparation methods yielded significantly different shear bond strengths. Er:YAG laser preparation of enamel yielded higher bond strengths compared with traditional preparation.
\end{abstract}

Keywords

Laser Conditioning; Er:YAG LASER; Shear Bond Strength; Dental Enamel

\section{Introduction}

In recent years, there has been a growing interest and several advances in the application of Light Amplification by Stimulated Emission of Radiation (LASER) in the oral cavity. Thus, different LASER systems evolved for different needs [Usumez, et al., 2002]. With the introduction of the Er: YAG LASER, it has become possible to remove enamel and dentin more effectively and efficiently than with other LASERs. Moreover, cavity preparation with Er: YAG LASER (LASER etching) has been proposed as an alternative to acid etching of enamel and dentin [De Moor and Delme, 2010].

Er:YAG LASER uses a $2.94 \mu \mathrm{m}$ wavelength emission, which is coincident with the main absorption band of water $(3 \mu \mathrm{m})$ and hydroxyapatite $(2.8 \mu \mathrm{m})$ [Firat, et al., 2012]. This causes a high and rapid absorption of the irradiation, resulting in a temperature increase at the site of application which leads to a rapid volume expansion and vaporization of the water. As a result, micro explosions are produced, causing disintegration of the hard tissue [Shahabi, et al., 2012]. Adhesion to the enamel surface is based on the infiltration of resin monomers into etched enamel. Nowadays, dental adhesives use two strategies: an etch-and-rinse (ER) and a self-etch (SE) approach. ER adhesives use a 30$40 \%$ phosphoric acid to etch enamel before adhesive is applied to the preparation. SE adhesives composed of acidic monomers [Ergucu, et al., 2007], do not require a separate acid-etch step and, on the contrary of ER adhesives, do not remove the smear layer. Self-etching 
(SE) systems have been advocated as a suitable replacement for ER systems [Erickson, et al., 2009], however, many studies have found that bond strengths to enamel provided by SE systems are lower when compared to the bond strength yielded by ER systems [Erickson, et al., 2009; Goracci, et al., 2004; Loguercio, et al., 2008; Perdigao, et al., 2005].

The use of Er:YAG LASER has been reported to yield a microretentive surface and open dentinal tubules, both apparently ideal for adhesion [Apel, et al., 2003; Chimello-Sousa, et al., 2006; Firat, et al., 2012] as a result of the microexplosions of tooth substrate and the greater volatilization of intertubular than that of peritubular dentin [De Munck, et al., 2002]. LASER is further described as a safe, effective, painless and comfortable tool for the removal of dental hard tissues [Obeidi, et al., 2009]. However, the use of LASER technology as an effective alternative to traditional mechanical instruments for cavity preparation still remains unclear.

There are controversial results regarding the effectiveness of Er:YAG LASER pretreatment of enamel and dentin [Amaral, et al., 2010; Carrieri, et al., 2007; Obeidi, et al., 2009] prior to bonding procedures. Most of the studies report lower SBS to enamel [De Munck, et al., 2002; Dunn, et al., 2005] while others show no differences in the results [Moldes, et al., 2009]. This contradictory results are probably due to the diversity of the parameters, methodologies or adhesive systems used [Leonetti Edos, et al., 2011]. There is also some controversy concerning the need of additional acid etching application to tooth tissues irradiated by Er:YAG LASER [Amaral, et al., 2010; Chimello-Sousa, et al., 2006].

Preparation with mechanical instruments produces a smear layer which contains hard particles, blood, bacteria and saliva that is dissolved by acid etching [Beer, et al., 2012]. When LASER preparation is performed no smear layer is formed, which may be beneficial for simplified adhesives, as smear layer could otherwise buffer the less acidic monomers, preventing monomer infiltration [Oliveira, et al., 2003].

The aim of this study was to evaluate the shear bond strength of different dental adhesives to enamel prepared by an Er:YAG LASER and compare the results to those obtained by the same adhesives to enamel prepared by mechanical means. The null hypothesis is that the surface preparation methods used did not influence the SBS values to enamel yielded by each different adhesive system. The other null hypothesis tested was that acid conditioning the LASER treated enamel did not influence the SBS values yielded by an ER adhesive system to that surface.

\section{Materials and Methods}

A total of 150 sound bovine incisors was extracted and kept in distilled water at $4^{\circ} \mathrm{C}$, for no longer than a month. After this period of time, teeth were kept in a $0.5 \%$ chloramine solution for a week and bisected with a microtome (Accuton-Struers, Ballerup, Denmark) to separate the crown from the root. They were then polished with a 240-grit sandpaper to create a flat surface (Carbimet Buehler-met, Buehler, Lake Bluff, IL). In groups 1 to 5 enamel surface preparations were performed using an Er-YAG LASER system (OpusDent $^{\mathrm{TM}}$, Lumenis company, London, United Kingdom, model SA5601000, series number 005-13201), with a power of $500 \mathrm{~mJ}$ and a $12 \mathrm{~Hz}$ frequency. A working distance of $1 \mathrm{~mm}$ was used in a defocused mode. In groups 6 to 10 approximately $0.5-\mathrm{mm}$ of enamel was removed from buccal surfaces of specimens with 320-grit sandpaper. Surfaces were inspected for a flat bonding area of at least $4 \times 4 \mathrm{~mm}$ with no dentin exposed. The specimens were then randomly divided into ten groups $(n=15)$ according to the dental adhesive system used (Table 1) (Group 1 and 6 - PA + ExciTE®; Group 2 and 7 -AdheSE®; Group 3 and 8 - FuturaBond ${ }^{\circledR}$ NR; Group 4 and 9 ExciTE® (without PA); Group 5 and $10-$ Xeno® V). A Mylar $^{\mathrm{TM}}$ adhesive strip with a $3 \mathrm{~mm}$ diameter hole was place on top of the enamel surface to standardize adhesive area. Materials were applied according to the manufacturer's instructions (Table 1). The adhesives were light-cured for 10 seconds (blue phase, Ivoclar Vivadent). After the application of the adhesive, composite resin cylinders (Fig. 1) were bonded to the tested surfaces (Synergy D6, A2/D2, Coltène Whaledent $\mathrm{GmbH}$, Langenau, Germany). Enamel specimens were then stored in water at $37^{\circ} \mathrm{C}$ for $24 \mathrm{~h}$ with $100 \%$ humidity (Hemmet, Schwabach, Germany) to allow for the post irradiation polymerization, and thermocycled (Aralab, mod 200E, Cascais, Portugal) for 500 cycles between 5 and $55^{\circ} \mathrm{C}$ with a dwell time of $20 \mathrm{~s}$. Samples were incorporated in a single plane shear lap device, and shear bond testing was accomplished using a Universal Testing Machine (Model 4502, series H3307, Instron Corporation, Bucks, England) at a crosshead speed of $0.5 \mathrm{~mm} / \mathrm{min}$ and a load cell of $1 \mathrm{KN}$. The force to failure was recorded for each specimen and the mean shear bond strength 
TABLE 1 COMPOSITION OF TESTED ADHESIVES

\begin{tabular}{|c|l|c|l|}
\hline Material/batch & \multicolumn{1}{|c|}{ Main component } & Manufacturer & \multicolumn{1}{|c|}{ Manufacturer's instructions } \\
\hline $\begin{array}{c}\text { Total etch } \\
\text { (N23886) }\end{array}$ & 37\% phosphoric acid. & $\begin{array}{c}\text { IvoclarVivadent } \\
\text { Schaan, } \\
\text { Liechtenstein }\end{array}$ & $\begin{array}{l}\text { Applied for 30s, rinsed for 15s, and gently dried for 5 } \\
\text { seconds }\end{array}$ \\
\hline $\begin{array}{c}\text { Excite } \\
\text { (P50689) }\end{array}$ & $\begin{array}{l}\text { HEMA, dimethacrylate, phosphonic acid acrylate, } \\
\text { highly dispersed silicon dioxide, initiators and } \\
\text { stabilizers, alcohol }\end{array}$ & $\begin{array}{c}\text { IvoclarVivadent } \\
\text { Schaan, } \\
\text { Liechtenstein }\end{array}$ & $\begin{array}{l}\text { Applied for 10 seconds, air dried for 15 seconds and } \\
\text { light-cured for 10 second light-curing }\end{array}$ \\
\hline $\begin{array}{c}\text { AdheSE } \\
\text { (Primer- } \\
\text { P30007 } \\
\text { Bond-P23053) }\end{array}$ & $\begin{array}{l}\text { Primer (dimethacrylate, phosphonic acid acrylate, } \\
\text { initiators and stabilizers in an aqueous solution) } \\
\text { Bond (HEMA, dimethacrylate, silicon dioxide, } \\
\text { initiators and stabilizers). }\end{array}$ & $\begin{array}{c}\text { IvoclarVivadent } \\
\text { Schaan, } \\
\text { Liechtenstein }\end{array}$ & $\begin{array}{l}\text { Primer applied with a brush for 15 seconds (total } \\
\text { reaction time should not be shorter than 30 seconds) } \\
\text { dispersed with a strong stream of air until the mobile } \\
\text { liquid was no longer visible. } \\
\text { Bond is applied and dispersed with a weak stream of } \\
\text { air and light cured for 10 seconds }\end{array}$ \\
\hline $\begin{array}{c}\text { FuturaBond } \\
\text { NR } \\
(0950214)\end{array}$ & $\begin{array}{l}\text { Organic acids, Bis-GMA, HEMA, TMPTMA, } \\
\text { camphorquinone, amines (DABE), BHT, fluorides } \\
\text { and ethanol. }\end{array}$ & $\begin{array}{c}\text { VOCO, } \\
\text { Cuxhaven, } \\
\text { Germany }\end{array}$ & $\begin{array}{l}\text { Applied in a thin layer and brushed for 20 second. air } \\
\text { dried for at least 5 seconds and polymerized for 10 } \\
\text { seconds. }\end{array}$ \\
\hline $\begin{array}{c}\text { Xeno V } \\
(1002000450)\end{array}$ & $\begin{array}{l}\text { Bifunctional acrylate, acid acrylate, functionalized } \\
\text { phosphoric acid ester, water, tertiary-butanol, } \\
\text { initiator and stabilizer. }\end{array}$ & $\begin{array}{l}\text { Dentsply,DeTrey } \\
\text { GmbH, Germany }\end{array}$ & $\begin{array}{l}\text { Applied into the whole cavity uniformly, agitated gently } \\
\text { for 20 seconds and the solvent evaporated with air } \\
\text { until there was no more movement of the adhesive }\end{array}$ \\
\hline
\end{tabular}

(MPa) was determined for each group. Data was tested for normality with Shapiro Wilks statistical test and analyzed with two-way ANOVA and StudentNewman-Keuls post-hoc test with a confidence level of $95 \%$. Pairwise comparisons were performed with a Bonferroni correction.

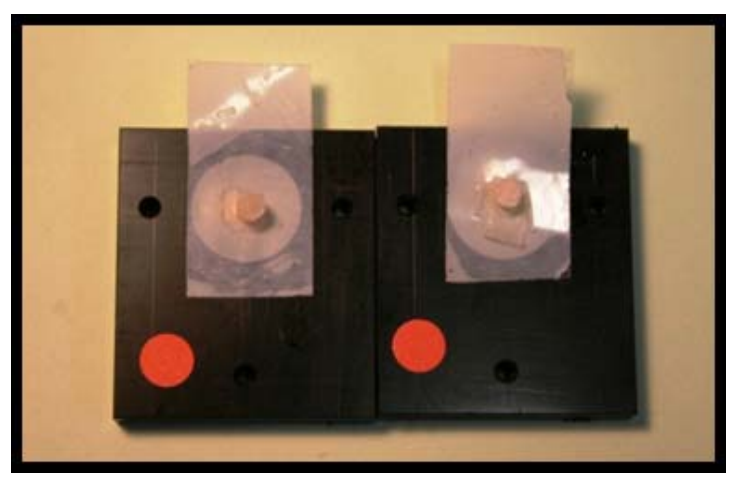

FIG. 1 COMPOSITE RESIN CYLINDERS BONDED TO THE TESTED SURFACE

\section{Failure Pattern Analyses}

The failure modes of the de-bonded surfaces were examined using a binocular stereomicroscope (SMZ-10, Nikon, Melville, NY, USA) at 15x magnification. Failures were classified in adhesive, cohesive within the enamel, adhesive or composite and mixed. Due to the type of data, it had to be analyzed with nonparametric tests. For each surface treatment Kruskal-wallis and Man Whitney, tests with Bonferroni correction were used. Representative samples were chosen for examination under SEM (JEOL JSM 6301F/Oxford INCA Energy 350/ Gatan Alto 2500, Tokyo, Japan) (Fig. 2). Samples goldsputtered and examined at $30 \mathrm{kV}$ accelerating voltage with different magnifications and characteristic photomicrographs were obtained at 2000x magnification.

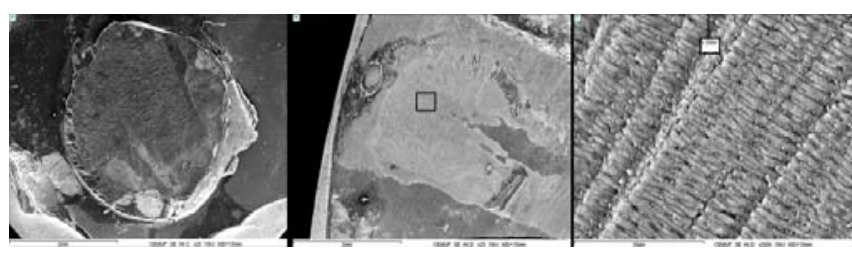

FIG. 2 EXAMPLE OF ADHESIVE FRACTURE BETWEEN ENAMEL AND ADHESIVE (CAPTION: A-COMPOSITE SURFACE MOSTLY COVERED BY THE ADHESIVE; B-ENAMEL SURFACE NOT COVERED BY THE ADHESIVE; C-ENAMEL SURFACE WITH ENAMEL RODS).

\section{Results}

\section{Shear Bond Strength}

Mean SBS values are depicted in Fig. 3.

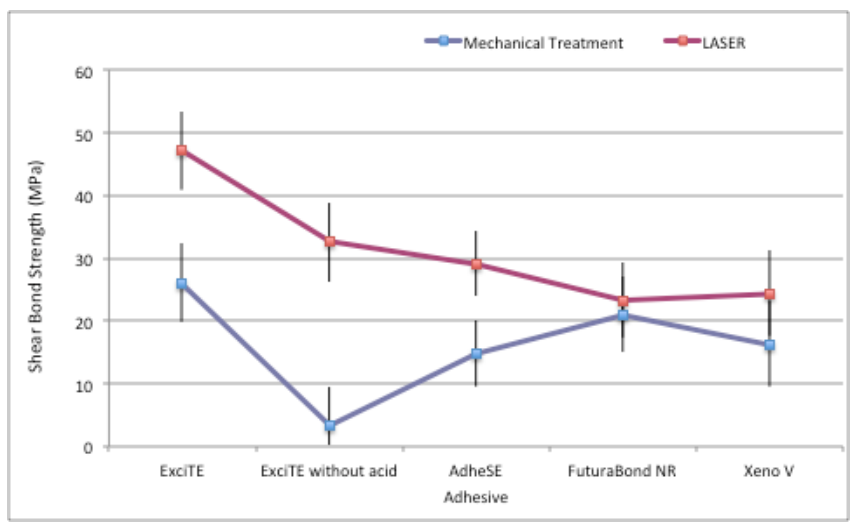

FIG. 3 MEAN SBS +/- STANDARD DEVIATION YIELDED BY THE ADHESIVE SYSTEMS TO THE TWO DIFFERENTLY PREPARED SURFACES.

SBS values were significantly influenced by the adhesive system used $(p=0,000)$ and by the enamel preparation $(\mathrm{p}=0,000)$ (Table 2$)$. Overall, the SBS to the LASER treated surfaces was higher than that of the mechanically treated surfaces. A significant interaction 
between surface treatment and adhesive system was detected $(p=0,000)$.

\section{TABLE 2 TWO WAY ANOVA}

Two Way ANOVA

Dependent Variable:Valoresderesistenciaadesiva

\begin{tabular}{|l|r|r|r|r|c|}
\hline Source & \multicolumn{1}{|c|}{$\begin{array}{c}\text { Type III Sum } \\
\text { of Squares }\end{array}$} & \multicolumn{1}{c|}{ df } & Mean Square & \multicolumn{1}{c|}{$\mathrm{F}$} & \multicolumn{1}{c|}{ Sig. } \\
\hline Corrected Model & $16091,845^{\mathrm{a}}$ & 9 & 1787,983 & 48,531 &, 000 \\
Intercept & 82853,673 & 1 & 82853,673 & 2248,903 &, 000 \\
Adhesive & 6185,266 & 4 & 1546,316 & 41,972 &, 000 \\
Surface treatment & 7902,545 & 1 & 7902,545 & 214,499 &, 000 \\
Adhesive * Surface & 2925,811 & 4 & 731,453 & 19,854 &, 000 \\
treatment & 5010,488 & 136 & 36,842 & & \\
Error & 108452,025 & 146 & & & \\
Total & 21102,332 & 145 & & & \\
Corrected Total & \multicolumn{2}{|l}{ a. R Squared =,763 (Adjusted R Squared =,747) } \\
\hline
\end{tabular}

Two one-way ANOVA's and Student-Newman-Keuls post-hoc tests were performed for each surface treatment group.

For the LASER enamel preparation Group 2 (29,10+/$5,21 \mathrm{MPa})$ and Group $4(32,56+/-6,36 \mathrm{MPa})$ were not significantly different as were not Group $3(23,32+/-$ $5,93 \mathrm{MPa})$ and Group 5(24,43+/-6,76 $\mathrm{MPa})(\mathrm{P}>0,05)$. Group $1(47,17+/-6,25 \mathrm{MPa})$ yielded significantly higher SBS values than the rest of the groups $(\mathrm{P}<0,05)$.

For the mechanical preparation, Group 9(3,25+/2,91MPa), Group $6(26,12+/-6,32 \mathrm{MPa})$ and Group 8 $(21,03+/-7,44 \mathrm{MPa})$ were significantly different from each other $(p<0,05)$. Group $7(14,77+/-3,47 \mathrm{MPa})$ and Group $10(16,38+/-7,64 \mathrm{MPa})$ did not yield significant differences from each other but different from the rest.

Five Pairwise comparisons were performed adjusting the confidence level with Bonferroni correction. Enamel surface preparation influenced the SBS yielded by every adhesive system, except by Futurabond NR $(p=0,304)$, which was probably the source for the interaction found in the two-way ANOVA test.

\section{Type of Fracture}

Figure 4 shows the bonding failure mode analysis after SBS test.

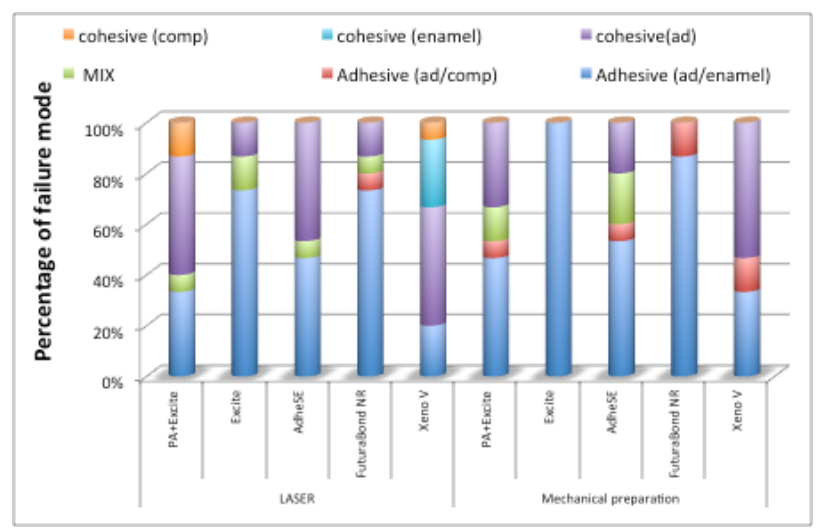

FIG. 4 PERCENTAGES OF BOND FAILURE MODE AFTER SBS TEST FOR EACH GROUP TESTED
Kruskal-wallis test revealed significant differences in failure mode influenced by the adhesive system and by the surface preparation method $(\mathrm{P}<0,05)$. None of the mechanical surface preparation specimens had cohesive failures in the composite or in the enamel. It can also be observed that Xeno $\mathrm{V}$ was the only adhesive yielding cohesive failures in enamel, and that this happened only in the LASER surface preparation specimens. Furthermore, the specimens bonded with this adhesive were the only ones that yielded no mixed failures in the LASER prepared specimens.

Adhesive failures (adhesive/enamel) were in higher number for the mechanical surface preparation (44) than for the LASER preparation (37). Cohesive in the adhesive failures were in higher number at the LASER prepared surfaces (25) than at the mechanical prepared specimens (16).

\section{Discussion}

An Er:YAG LASER was used to prepare enamel. Several authors stated that treating enamel with LASERs would produce a rougher surface than using a diamond bur, which can be useful for enamel etching. In fact, some authors suggested that LASER treatment could serve as a valid alternative for acidetching and enhance the bond strength between restorative materials and dental tissues [Ergucu, et al., 2007; Yu, et al., 2003], especially for the use of selfetching adhesive.

The mechanism of tissue removal by LASER, unlike acid etching, is not demineralization. Instead, a microablative process causes vaporization of water and dental organic components, promoting micro explosions, which on their turn, causes the destruction of inorganic substances [Shahabi, et al., 2012] resulting in microscopic surface irregularities in which the adhesive system can penetrate, fostering retention and thus good SBS values are obtained (Fig. 5) [Sasaki, et al., 2008].

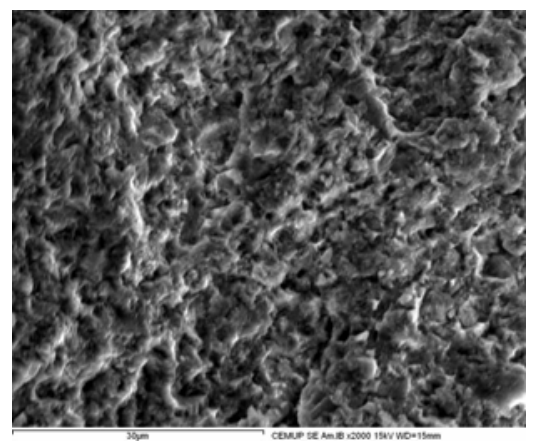

FIG. 5 LASER TREATED ENAMEL SURFACE SHOWING SURFACE IRREGULARITIES 
Moreover, some disadvantages attributed to acid etching such as increase in permeability and susceptibility to secondary caries formation can be avoided [Shahabi, et al., 2012]. However contradictory results of SBS have been reported.

In the present study, the mechanical preparation of the enamel surface was not done with bur, due to the technical difficulty and to preservation of the standardization of the samples. A 320-grit sandpaper was chosen, to create a smear layer closer to the one created by a bur [Oliveira, et al., 2003], since when selfetching materials are tested, the smear layer thickness is extremely important.

For this study, bovine teeth were used as a substitute for human's as it has been shown that the former is a reliable substitute for bonding strength tests on dental enamel [Tsujimoto, et al., 2010; Yassen, et al., 2011].

\section{Shear Bond Strength Test}

Some authors stated that enamel prepared with LASER decreases SBS values compared to rotatory instruments [Obeidi, et al., 2009]. While others stated that SBS values are identical [De Munck, et al., 2002]. Different LASER outputs used or the different characteristics of the adhesive systems employed may explain this discrepancy [Cardoso, et al., 2008].

Preparation of enamel with rotatory instruments, unlike LASER preparation, leaves a smear layer on the surface. The smear layer inhibits the impregnation of enamel with the adhesive agent, and thus preventing adequate adhesion [Buonocore, et al., 1968]. Acid etching is therefore recommended for the removal of this smear layer and to demineralize the subsurface when mechanical preparation is used to prepare enamel [Beer, et al., 2012]. Some authors suggested that some simplified SE adhesives that use less acidic monomers than phosphoric acid, could not produce a reliable SBS to enamel as opposed to strong SE that seems to produce higher bond strengths on enamel [Breschi, et al., 2003, Hipolito, et al., 2011]. In the present study, mean SBS values obtained for the SE adhesives were acceptable when enamel was mechanical eroded, however, their performance was enhanced when enamel was prepared by LASER, except for FuturaBond NR that had similar results for both types of enamel preparation. The different results between the SE groups can be attributed to their composition. The differences obtained by the two different preparations (LASER vs mechanical) can be attributed to the absence of smear layer, as LASER does not produce a smear layer that may prevent the bonding penetration and, thus decreasing SBS values, especially for medium-strong SE systems which are generally buffered by thick smear layers [Hossain, et al., 2003]. One other explanation may be related to the fact that LASER seems to produce an etching pattern suitable for good adhesion [Basaran, et al., 2011], and finally the good SBS values of the groups prepared with LASER may be explained by the chemical bonding of monomers to hydroxyapatite [Van Meerbeek, et al., 2011].

When enamel is prepared with LASER, there are statistically significant differences $(p<0,05)$ between applications of acid etch. When Excite is applied to enamel without decreasing acid etching SBS values, when compared to samples that were LASER treated and phosphoric acid etched (32,56 $\mathrm{MPa}$ and 47,17 $\mathrm{MPa}$ respectively). This is in accordance to other studies finding that the conjunction of the LASER irradiation with the acid etching results in higher SBS values [Firat, et al., 2012, Sasaki, et al., 2008]. This can occur as acid etching can etch enamel that LASER could not etch alone, as LASER has shown in other studies uneven etching surfaces [Hossain, et al., 1999]. However, unlike most of the studies [Firat, et al., 2012, Shahabi, et al., 2012] LASER irradiation showed strong capability of etching enamel without the subsequent etch by phosphoric acid and, surprisingly, achieving better values than enamel those prepared by mechanical means and treated with phosphoric acid (32,56 MPa and 26,12 MPa, respectively). These results could be related to the etching pattern left after acid etching, which could be rougher in the LASER irradiation surface.

\section{Failure Pattern Analyses}

Failure pattern should be examined carefully to identify the origin of failure, as this may help better understand the scope and limitations of dental adhesives as well as possible mechanisms to develop better adhesive systems.

In the present study, statistically significant differences $(p<0,05)$ were found in the failure pattern between the two types of enamel preparation

Several studies [Borges, et al., 2007, Kahveci and Belli, 2011] have stated that cohesive failures are related to higher SBS values, which is in accordance with the present results, where the cohesive failures were in higher number at the LASER treated specimens, and therefore the higher SBS values observed at the LASER 
treated specimens could be explained. On the opposite, adhesive failures between the tooth and the adhesive are related to lower SBS values, however, there are no explanations for this association [Phrukkanon, et al., 1998]. Furthermore, the adhesive failueres between enamel and adhesive were in lower number in the LASER treated specimens for all the adhesive systems tested, revealing a better bond between the adhesive systems and the enamel in the LASER treated specimens.

The fact that cohesive failures in the enamel only present at the LASER treated specimens suggests that LASER promotes rupture due to the micro-explosions that can weaken enamel, originating heterogenic surfaces as opposite to the mechanical abrasion surfaces. However, this was only verified with one of the adhesive systems tested (XenoV). Some difference could occur in the adhesion promoted by this adhesive system since the power of demineralization of the selfetching adhesive depends on various factors: pKa (acid dissociation constant), the structure of the primer components (which may be more or less chelating) and the solubility of the salts formed and the application time [Britta, et al., 2009]. These differences could have led to the weakening of a fragile surface, explaining the enamel cohesive failure observed for this adhesive system. One other explanation may be due to the fragmented particles that are produced when the enamel is irradiated by the Er: Yag LASER that can be outbreaks of failure because they are on the tooth without being hooked [Shahabi, et al., 2012]. Since only Xeno V gave rise to these failures, it could be thought that Xeno V did not properly infiltrate the surface interacting only with the particles described, and not with the underlying enamel, leading to cohesive failures at the enamel bond and lower strength values than other systems with adhesive failures.

The different types of failure are still statistically significant when we look separately to the influence of LASER preparation and mechanical preparation ( $p$ $<0.05)$. These results suggest that the type of adhesive is indeed a factor related to the type of failure, and that there is an interaction between the two factors (adhesive and type of preparation) in relation to the type of failure. A recent study showed that for each type of adhesive it appears to be a predominant type of failure and a specific value of adhesive strength due to it interaction with enamel [Hipolito, et al., 2011].

\section{Conclusions}

LASER preparation of enamel produced higher SBS values in comparison to the mechanical preparation. SBS values of SE systems to LASER treated surfaces were higher than those to the mechanical prepared surfaces and should be more predictable and dependable without the disadvantages resulting from selective etching with phosphoric acid. When an ER system is applied to the LASER prepared surface, SBS values also increase; however, good results are also obtained without the use of phosphoric acid when a two component adhesive system is used. The null hypotheses were therefore rejected. The surface preparation method influenced the SBS yielded by the different adhesives to enamel. Mean SBS values yielded by an ER adhesive system to LASER treated enamel were higher if the surface was acid-etched previously.

\section{ACKNOWLEDGMENT}

This paper is based on a thesis submitted to Dental Medicine faculty of University of Porto, in partial fulfilment of the requirements for the Doctor degree.

\section{REFERENCES}

Amaral, F.L., Colucci, V., Souza-Gabriel, A.E., Chinelatti, M.A., Palma-Dibb, R.G., and Corona, S.A., "Bond durability in erbium:yttrium-aluminum-garnet laserirradiated enamel". Lasers Med Sci, Vol.25, pp.155-163, 2010.

Apel, C., Schafer, C., and Gutknercht, N., "Demineralization of Er:YAG and Er,Cr:YSGG laser-prepared enamel cavities in vitro.". Caries Res, Vol.37, pp.34-37, 2003.

Basaran, E.G., Ayna, E., Basaran, G., and Beydemir, K., "Influence of different power outputs of erbium, chromium:yttrium-scandium-gallium-garnet laser and acid etching on shear bond strengths of a dual-cure resin cement to enamel". Lasers Med Sci, Vol.26, pp.13-19, 2011

Beer, F., Buchmair, A., Korpert, W., Marvastian, L., Wernisch, J., and Moritz, A., "Morphology of resin-dentin interfaces after Er,Cr:YSGG laser and acid etching preparation and application of different bonding systems". Lasers Med Sci, Vol.27, pp.835-841, 2012.

Borges, M.A., Matos, I.C., and Dias, K.R., "Influence of two self-etching primer systems on enamel adhesion". Braz Dent J, Vol.18, pp.113-118, 2007. 
Breschi, L., Gobbi, P., Falconi, M., Mazzotti, G., Prati, C., and Perdigao, J., "Ultra-morphology of self-etching adhesives on ground enamel: a high resolution SEM study". Am J Dent, Vol.16 Spec No, pp.57A-62A, 2003.

Britta, L.C., Martins, M., and Franca, F.M., "Influence of different primer application times on bond strength of self-etching adhesive systems to unground enamel". Oper Dent, Vol.34, pp.43-50, 2009.

Buonocore, M.G., Matsui, A., and Gwinnett, A.J., "Penetration of resin dental materials into enamel surfaces with reference to bonding". Arch Oral Biol, Vol.13, pp.61-70, 1968.

Cardoso, M.V., De Munck, J., Coutinho, E., Ermis, R.B., Van Landuyt, K., de Carvalho, R.C., and Van Meerbeek, B., "Influence of Er,Cr:YSGG laser treatment on microtensile bond strength of adhesives to enamel". Oper Dent, Vol.33, pp.448-455, 2008.

Carrieri, T.C., de Freitas, P.M., Navarro, R.S., Eduardo Cde, P., and Mori, M., "Adhesion of composite luting cement to Er:YAG-laser-treated dentin". Lasers Med Sci, Vol.22, pp.165-170, 2007.

Chimello-Sousa, D.T., de Souza, A.E., Chinelatti, M.A., Pecora, J.D., Palma-Dibb, R.G., and Milori Corona, S.A., "Influence of Er:YAG laser irradiation distance on the bond strength of a restorative system to enamel". J Dent, Vol.34, pp.245-251, 2006.

De Moor, R.J., and Delme, K.I., "Laser-assisted cavity preparation and adhesion to erbium-lased tooth structure: part 2. present-day adhesion to erbium-lased tooth structure in permanent teeth". J Adhes Dent, Vol.12, pp.91-102, 2010.

De Munck, J., Van Meerbeek, B., Yudhira, R., Lambrechts, P., and Vanherle, G., "Micro-tensile bond strength of two adhesives to Erbium:YAG-lased vs. bur-cut enamel and dentin". Eur J Oral Sci, Vol.110, pp.322-329, 2002.

Dostalova, T., Jelinkova, H., Krejsa, O., Hamal, K., Kubelka, J., and Prochazka, S., "Er:YAG laser radiation etching of enamel". P Soc Photo-Opt Ins, Vol.2922, pp.90-97, 1996.

Dunn, W.J., Davis, J.T., and Bush, A.C., "Shear bond strength and SEM evaluation of composite bonded to Er:YAG laser-prepared dentin and enamel". Dent Mater, Vol.21, pp.616-624, 2005.

Ergucu, Z., Celik, E.U., and Turkun, M., "Microleakage study of different adhesive systems in Class $\mathrm{V}$ cavities prepared by Er,Cr:YSGG laser and bur preparation". Gen Dent, Vol.55, pp.27-32, 2007.

Erickson, R.L., Barkmeier, W.W., and Kimmes, N.S., "Bond strength of self-etch adhesives to pre-etched enamel". Dent Mater, Vol.25, pp.1187-1194, 2009.

Firat, E., Gurgan, S., and Gutknecht, N., "Microtensile bond strength of an etch-and-rinse adhesive to enamel and dentin after Er:YAG laser pretreatment with different pulse durations". Lasers Med Sci, Vol.27, pp.15-21, 2012.

Goracci, C., Bertelli, E., and Ferrari, M., "Bonding to worn or fractured incisal edges: shear bond strength of new adhesive systems". Quintessence Int, Vol.35, pp.21-27, 2004.

Goswami, M., and Singh, A., "Comparative evaluation of shear bond strength of composite resin bonded to acid etched or Nd:Yag lased enamel". J Indian Soc Pedod Prev Dent, Vol.29, pp.140-143, 2011.

Hipolito, V.D., Alonso, R.C., Carrilho, M.R., Anauate Netto, C., Sinhoreti, M.A., and Goes, M.F., "Microtensile bond strength test and failure analysis to assess bonding characteristics of different adhesion approaches to ground versus unground enamel". Braz Dent J, Vol.22, pp.122-128, 2011.

Hossain, M., Nakamura, Y., Yamada, Y., Kimura, Y., Nakamura, G., and Matsumoto, K., "Ablation depths and morphological changes in human enamel and dentin after Er:YAG laser irradiation with or without water mist". J Clin Laser Med Surg, Vol.17, pp.105-109, 1999.

Hossain, M., Yamada, Y., Nakamura, Y., Murakami, Y., Tamaki, Y., and Matsumoto, K., "A study on surface roughness and microleakage test in cavities prepared by Er:YAG laser irradiation and etched bur cavities". Lasers Med Sci, Vol.18, pp.25-31, 2003.

Kahveci, O., and Belli, S., "Composite bond strength to intact enamel with current simplified adhesives". J Adhes Dent, Vol.13, pp.31-37, 2011.

Leonetti Edos, S., Rodrigues, J.A., Reis, A.F., Navarro, R.S., Aranha, A.C., and Cassoni, A., "Effects of Er:YAG laser irradiation on the microtensile bond strength to bleached enamel". Photomed Laser Surg, Vol.29, pp.551-558, 2011.

Loguercio, A.D., Moura, S.K., Pellizzaro, A., Dal-Bianco, K., Patzlaff, R.T., Grande, R.H., and Reis, A., "Durability of 
enamel bonding using two-step self-etch systems on ground and unground enamel". Oper Dent, Vol.33, pp.79-88, 2008.

Moldes, V.L., Capp, C.I., Navarro, R.S., Matos, A.B., Youssef, M.N., and Cassoni, A., "In vitro microleakage of composite restorations prepared by Er:YAG/Er,Cr:YSGG lasers and conventional drills associated with two adhesive systems". J Adhes Dent, Vol.11, pp.221-229, 2009.

Obeidi, A., McCracken, M.S., Liu, P.R., Litaker, M.S., Beck, P., and Rahemtulla, F., "Enhancement of bonding to enamel and dentin prepared by Er,Cr:YSGG laser". Lasers Surg Med, Vol.41, pp.454-462, 2009.

Oliveira, S.S., Pugach, M.K., Hilton, J.F., Watanabe, L.G., Marshall, S.J., and Marshall, G.W., Jr., "The influence of the dentin smear layer on adhesion: a self-etching primer vs. a total-etch system". Dent Mater, Vol.19, pp.758-767, 2003.

Perdigao, J., Gomes, G., Duarte, S., Jr., and Lopes, M.M., "Enamel bond strengths of pairs of adhesives from the same manufacturer". Oper Dent, Vol.30, pp.492-499, 2005.

Phrukkanon, S., Burrow, M.F., and Tyas, M.J., "Effect of cross-sectional surface area on bond strengths between resin and dentin". Dent Mater, Vol.14, pp.120-128, 1998.

Sasaki, L.H., Lobo, P.D., Moriyama, Y., Watanabe, I.S., Villaverde, A.B., Tanaka, C.S., Moriyama, E.H., and
Brugnera, A., Jr., "Tensile bond strength and SEM analysis of enamel etched with Er:YAG laser and phosphoric acid: a comparative study in vitro". Braz Dent J, Vol.19, pp.57-61, 2008.

Shahabi, S., Bagheri, H.G., and Ramazani, K., "Tensile bond strength of sealants following Er:YAG laser etching compared to acid etching in permanent teeth". Lasers Med Sci, Vol.27, pp.371-375, 2012.

Tsujimoto, A., Iwasa, M., Shimamura, Y., Murayama, R., Takamizawa, T., and Miyazaki, M., "Enamel bonding of single-step self-etch adhesives: influence of surface energy characteristics". J Dent, Vol.38, pp.123-130, 2010.

Usumez, S., Orhan, M., and Usumez, A., "Laser etching of enamel for direct bonding with an Er,Cr:YSGG hydrokinetic laser system". Am J Orthod Dentofacial Orthop, Vol.122, pp.649-656, 2002.

Van Meerbeek, B., Yoshihara, K., Yoshida, Y., Mine, A., De Munck, J., and Van Landuyt, K.L., "State of the art of selfetch adhesives". Dent Mater, Vol.27, pp.17-28, 2011.

Yassen, G.H., Platt, J.A., and Hara, A.T., "Bovine teeth as substitute for human teeth in dental research: a review of literature". J Oral Sci, Vol.53, pp.273-282, 2011.

Yu, J., Jia, X., and Qiao, L., "[A scanning electron microscopy study on morphological changes of Er, Cr: YSGG lasercutted dental hard tissue]". Hua Xi Kou Qiang Yi Xue Za Zhi, Vol.21, pp.356-358, 2003. 